\title{
Co-Inoculation by Spraying on Soybean (Glycine max L.) Under Vegetative Phase
}

\author{
Gustavo de Souza Toniato, Álvaro Andrade Baena Aguilar \\ Universidade Paranaense - UNIPAR, Campus III. Avenida Tiradentes, 3240 - Jardim Paraíso, \\ Umuarama, PR, Brazil
}

\section{Pedro Henrique Riboldi Monteiro}

Universidade Federal dos Vales do Jequitinhonha e Mucuri - UFVJM, Campus JK. Rodovia MGT 367 - Km 583, nº 5.000 - Alto da Jacuba, Diamantina, MG, Brazil

Wesley Ribeiro Rivadavea, Juliane Destro de Lima, Odair Alberton, Glacy Jaqueline da Silva (Corresponding author)

Universidade Paranaense - UNIPAR, Campus III. Avenida Tiradentes, 3240 - Jardim Paraíso, Umuarama, PR, Brazil. E-mail: glacyjaqueline@prof.unipar.br

Received: Apr. 12, $2020 \quad$ Accepted: May 6, $2020 \quad$ Published: May 12, 2020

doi:10.5296/jas.v8i3.16824 URL: https://doi.org/10.5296/jas.v8i3.16824

\begin{abstract}
The use of inoculants revolutionized the soybean production system, increasing grain production, reducing the use of chemical fertilizers, and costs. The inoculation with Bradyrhizobium japonicum and the co-inoculation with more than one type of microorganisms are recommended directly in the seed or in the planting furrow, with high efficiency, bringing beneficial results related to the increase in the number of nodules and improvements in the physiology of the soybean plants. In order to increase productivity bringing new methods of using these microorganisms, this study aimed to evaluate the development of soybean culture under co-inoculation by spraying with Azospirilum brasilense and B. japonicum was carried out, in the vegetative stage. One field experiment was conducted from September to January, harvest of 2018/2019, in the commercial area under no-tillage. The evaluated treatments were: Control (C) without microorganisms; T1 $\left(6 \times 10^{8} \mathrm{~mL}^{-1}\right.$ of $A$. brasilense and 0 of B. japonicum); T2 $\left(6 \times 10^{8} \mathrm{~mL}^{-1}\right.$ of A. brasilense and $6 \times 10^{9} \mathrm{~mL}^{-1}$ of $B$. japonicum $)$; T3 $\left(12 \times 10^{8} \mathrm{~mL}^{-1}\right.$ of $A$. brasilense and 0 of $B$. japonicum $)$; and $\mathrm{T} 4\left(12 \times 10^{8} \mathrm{~mL}^{-1}\right.$ of $A$. brasilense and $12 \times 10^{9} \mathrm{~mL}^{-1}$ of $B$. japonicum). The results showed that
\end{abstract}


there was an increase in the number and matter of nodules, plant height, number of pods and grains in the T4 treatment, showing a significant difference mainly in relation to the control. It was concluded that co-inoculation with B. japonicum and A. brasilense by spraying in the vegetative stage proved to be efficient, demonstrating the potential use of this technique.

Keywords: biological nitrogen fixation, diazotrophic bacteria, Glycine max, productivity

\section{Introduction}

\subsection{Soybean and the Nitrogen}

Soybean (Glycine max L.) is one of the main commodities in the world. The soybean cultivation for grain production aims the multiple uses of agribusiness, such as production of vegetable oil, animal feed, chemical and food industry, in addition to being an alternative source of biofuel (Khomina et al., 2020). In the last thirty years, Brazil has become the second largest producer and exporter of soybean (grain and bran) in the world, with a share of more than $33 \%$ of the world market (FAO, 2018). For farmers, one of the reasons that make soybean commercially viable is the use of inoculants based on biological nitrogen fixation (BNF) by diazotrophic bacteria (Galindo et al., 2018).

Nitrogen is the most required nutrient for soybean, and therefore, the crop is very dependent on nitrogen fertilizers (Erdiansyah et al., 2020). With BNF technology and the use of the seed inoculation technique, it is possible to save about 3 billion dollars annually, maintaining excellent productivity (Hungria et al. 2005), since the bacteria supply the nitrogen needs required by the plant.

\subsection{Nitrogen-Fixing Bacteria and Plant Growth Promoting Bacteria}

Bacteria of the genus Bradyrhizobium are widely recommended for application in soybean, due to their high performance with this crop, combined with low cost (de Quadros et al., 2020). Without the use of nitrogen fertilizers, studies conducted in Argentina and Brazil revealed productivity around $6000 \mathrm{~kg} \mathrm{ha}^{-1}$ with Bradyrhizobium strains (Zotarelli, 2000; Hungria et al., 2006).

However, there are some studies that report the use of co-inoculation (Prando et al., 2019; de Quadros et al., 2020). In soybean, the co-inoculation of B. japonicum and Azospirillum brasilense generally occurs with positive response in plant productivity (Chibeba et al., 2015). Bacteria of the Azospirillum genus have the ability to stimulate the production of phytohormones in significant quantities, promoting the development of plants (Bulegon et al., 2016). Study has revealed that the species A. brasilense has the capacity to produce the hormones such as auxins, gibberellins and cytokinins (Masciarelli et al., 2013).

\subsection{Application Techniques of Microorganisms}

The recommended methodology for applying inoculants is usually performed directly on the seed, before sowing. The furrow application is being used by some research institutions and farmers with satisfactory results (Hungria et al., 2013). However, due to weather conditions, failures often occur in the nodules formation on the roots and consequently less supply of 
nitrogen $(\mathrm{N})$ to the plant. Thus, to avoid loss of productivity, farmers are applying $\mathrm{N}$ mineral fertilizer, which avoid the problem, but increases the production costs. Some research centers have developed, on an experimental level, the application of inoculants by alternative techniques. Abido and Omar, (2020) obtained excellent response of productivity and fertility with fert-irrigation with Bradyrhizobium and humic substances in soybean. Results with spray application were also satisfactory for soybeans (Ceribeli, 2019), and beans, after sowing (Garé, 2020).

Trying to validate and inform efficient application methods, the aims of this study was to evaluate the development of soybean under co-inoculation by combined spraying of $B$. japonicum and A. brasilense, in the vegetative stage in the field condition and no-tillege.

\section{Materials and Methods}

\subsection{Experimental Area}

The experiment was performed in a field trial in the 2018/2019 during the months of September and January. The experimental area is located in Juranda (24'33'92.5'S and 52 $2^{\circ}$ '98.8'W), Midwest region of Paraná State, Brazil. The site has the soil classified as Dystrophic Red Latosol (Oxisoil) (Bhering et al., 2007).

\subsection{Soil Preparation, Sowing and Cultivation}

The soil preparation of the experimental area was accomplished two months in advance, with the adoption of liming to correct the acidity of the soil, using two tons per hectare of dolomitic limestone, according to the soil analysis recommendation; and desiccation with herbicide of the area following technical recommendation.

The seed sowing was the culivar NA 5909 RG by the company Nidera Sementes ${ }^{\circledR}$. The seeds were treated with IST (industrial seed treatment) with Dermacor® (Chlorantraniliprole) in a concentration of $50 \mathrm{~mL}$ for each $100 \mathrm{~kg}$ of seeds.

The experiment was sown under no-tillage system, with a basic fertilization of $310 \mathrm{~kg}$ per hectare with formulation 2-23-23 NPK and with the addition of B. japonicum peat inoculant. (Strains: Semia 5019 and Semia 587) respecting the manufacturer's technical recommendations. The spacing between lines was $0.45 \mathrm{~m}$ and the spacing between plants was eight $\mathrm{cm}$, totaling 16 seeds per linear meter. Each plot consisted of six lines, totaling $21.6 \mathrm{~m}^{2}$ for each treatment.

During the plant growth was carried out two applications of Tefubenzuron and one application of Diflubenzuron, both insecticides for caterpillars; two applications of Acephate + Aluminum Silicate, an insecticide used to control bedbugs; one application of Roundup ${ }^{\circledR}$ to control weed plants; one application of Protioconazole + Trifloxystrobin and one application of Azoxystrobin + Benzovindiflupir, both fungicides.

\subsection{Experimental Treatments}

Five treatments were carried out, in addition to the control (C), without the application of inoculants on the seeds. The treatments by spray consisted of: $\mathrm{T} 1-6 \times 10^{8} \mathrm{~mL}^{-1}$ of $A$. 
brasilense and 0 of $B$. japonicum; T2 $-6 \times 10^{8} \mathrm{~mL}^{-1}$ of $A$. brasilense and $6 \times 10^{9} \mathrm{~mL}^{-1}$ of $B$. japonicum; T3 - $12 \times 10^{8} \mathrm{~mL}^{-1}$ of $A$. brasilense and 0 of $B$. japonicum; and $\mathrm{T} 4-12 \times 10^{8} \mathrm{~mL}^{-1}$ of A. brasilense and $12 \times 10^{9} \mathrm{~mL}^{-1}$ of B. japonicum. Each treatment with four repetitions, totaling 20 experimental plots.

The foliar application of the inoculants (B. japonicum and A. brasilense) was done with the aid of a five L costal pump, having only one directed jet nozzle. The application was carried out at the V4 plant development stage, 36 days after sowing. The commercial inoculants used were Masterfix L Gramíneas ${ }^{\circledR}$ (A. brasilense - $1 \times 10^{8} \mathrm{~mL}^{-1}$ ) with strains AbV-5 and AbV-6 and Masterfix L Premier® (B. japonicum - $1 \times 10^{9} \mathrm{~mL}^{-1}$ ) with strains Semia 5019 and Semia 5079 .

\subsection{Parameters Evaluated}

With 49 days after sowing and 13 days after inoculants application, that is, in stage V6, the plants were collected for evaluation. Five plants were collected at random, per plot, being collected only from the two central lines, always two meters away from the end of the plots, totaling 100 plants. After the R8 stage, pods were collected.

The parameters evaluated were: $(\mathrm{PH})$ plant height $(\mathrm{cm}),(\mathrm{SD})$ stem diameter $(\mathrm{cm}),(\mathrm{NN})$ number of nodules, (DMN) dry matter of nodules (g), (DMR) dry matter of the root ( $\mathrm{g}$ ), (DMA) shoot dry matter (g), (NP) number of pods, (NG) number of grains, (GP) grains per pod and (MTS) mass of a thousand seeds.

\subsection{Statistical Analysis}

The design used was randomized blocks and the means obtained for each parameters variable were subjected to analysis of variance (ANOVA) and compared by means test usingDuncan's statistical test, with a probability of error of 5\%. The statistical program used was SPSS v22.

\section{Results and Discussion}

\subsection{Number of Nodules and Dry Mass of Nodules}

The number and matter of nodules (Table 1), increased significantly with spray inoculation. The response of the treatments, in ascending order, were T3, T1 and T4. These treatments obtained an average increase that varied from approximately $16.7 \%, 21.5 \%$ and $60.3 \%$ respectively. The T4 treatment indicates that the composition of 12 doses of A. brasilense and $B$. japonicum served as reinforcement to the seed inoculation, demonstrating the potential of using this technique.

Table 1. Number $\left(\mathrm{NN}\right.$ plant $\left.^{-1}\right)$ and dry matter of nodules $\left(\mathrm{DMN}-\mathrm{g} \mathrm{plant}^{-1}\right)$

\begin{tabular}{lll}
\hline Treatment & NN & DMN \\
\hline C & $180.50 \pm 19.93 \mathrm{~b}$ & $0.65 \pm 0.06 \mathrm{~b}$ \\
T1 & $219.25 \pm 21.55 \mathrm{ab}$ & $0.88 \pm 0.15 \mathrm{ab}$ \\
T2 & $185.00 \pm 8.61 \mathrm{~b}$ & $0.66 \pm 0.06 \mathrm{~b}$ \\
T3 & $210.50 \pm 21.62 \mathrm{ab}$ & $0.62 \pm 0.06 \mathrm{~b}$ \\
T4 & $289.50 \pm 51.82 \mathrm{a}$ & $1.10 \pm 0.15 \mathrm{a}$ \\
\hline
\end{tabular}


Mean values ( $\mathrm{n}=5 \pm$ standard error); different letters in the same column differ significantly by the Duncan test $(p \leq 0.05)$.

C - Control; T1 - Treatment 1; T2 - Treatment 2; T3 - Treatment 3; T4 - Treatment 4.

The $\mathrm{T} 1$ and $\mathrm{T} 3$ treatments resulted in lower responses compared to the T4. The explanation may be the failure to use the bacterium $B$. japonicum, which is the recommended strain as an inoculant in seeds for soybean cultivation. Studies report that the use of A. brasilensis in agricultural soils is highly dependent on the ability of this bacterium to compete with the diazotrophic bacteria native to the soil (Didonet et al., 2000). It is possible that a concentration of only $A$. brasilensis inoculated in vegetative stage by spray, may have provided the best development of secondary and adventitious roots, and thus, improving nodulation coming from bacteria that were already present in the initial treatment of seeds or present in the soil and rhizosphere.

The T2 treatment, with co-inoculation of A. brasilense and B. japonicum, did not show the same tendency to increase the number of nodules, obtaining lower results than the treatments with the inoculation of only A. brasilense and being similar to the control, in which was no inoculated. However, some factors may have contributed to this adverse result, such as failure to inoculation, high adherence and adherence of the solution to the leaf surface of the plant, i.e., the solution was unable to reach the soil in an adequate volume; or even the soil where this treatment was located could present a population concentration of native bacteria that did not allow the development and/or synergism of the solution from the treatment.

The dry matter of the nodules also had positive effects for treatments $\mathrm{T} 1$ and $\mathrm{T} 4$, the same ones that obtained the highets response for the parameter number of nodules (Table 1). These treatments showed that there was an increase in the weight of nodules with an average variation of $35 \%$ to $69 \%$ respectively. According to Souza et al. (2008), the parameters number and matter of nodules have a direct correlation with BNF, which are the most suitable variables to monitor planting performance. This data provides subsidies so that the T1 and T4 treatments are the most suitable to be implemented in the soy production system, with this spray co-inoculation technique.

The T4 treatment obtained the best results when compared to the T1 treatment, probably because it has a higher concentration of inoculants in the composition. This provided higher nodulation and also higher growth of nodules. This result is consistent, since higher doses of bacteria produces more nodules, which possibly led to a greater growth of these same nodules and consequently greater activity of the nodules in BNF (Groppa et al., 1998; Zilli et al., 2006).

In the spray inoculation strategy, it can be observed that most nodules were formed in secondary roots of soybean plants and close to the soil surface. This was because in that root zone there was a greater cellular differentiation for the development of the roots, at the moment of inoculation, allowing the exchange of molecular signals with the bacteria. Probably, it was also in this area of the soil profile where the bacteria that were applied by spraying are concentrated (Boonkerd et al., 1985). 


\subsection{Morphological Analysis of Soybean Plants}

The results of the morphological parameters of the soybean plants, with 49 days after sowing at stage V6 of the vegetative phase, are shown in table 2. Regarding plant height, the T4 treatment obtained significantly higher response. A similar result was also found by other authors, demonstrating that in high concentrations, the co-inoculation of B. japonicum and $A$. brasilense is beneficial for soybean crop (Crozier et al., 1988; Reis et al., 2008). Pii et al. (2019), as well as others authors reported that phytohormones, mainly indole acetic acid (IAA), excreted by Azospirillum play an essential role in plant growth promoting bacteria in general. In addition, A. brasilense bacteria act directly on the plant, inducing the absorption of important nutrients such as nitrogen, phosphorus, iron and potassium. These nutrients assist in better plant development and growth (Coniglio et al., 2019).

Table 2. Stem diameter (SD - cm plant ${ }^{-1}$ ), Plant height (PH - $\left.\mathrm{cm} \mathrm{plant}^{-1}\right)$, Root dry matter $\left(\mathrm{RDM}-\mathrm{g} \mathrm{plant}^{-1}\right)$, Shoot dry matter $\left(\mathrm{SDM}-\mathrm{g}\right.$ plant $\left.^{-1}\right)$ part of soybean plants in stage V6

\begin{tabular}{ccccc}
\hline Treatment & SD & PH & RDM & SDM \\
\hline C & $1.45 \pm 0.15 \mathrm{a}$ & $20.85 \pm 1.18 \mathrm{~b}$ & $3.02 \pm 0.32 \mathrm{a}$ & $12.93 \pm 1.87 \mathrm{a}$ \\
$\mathrm{T} 1$ & $1.70 \pm 0.06 \mathrm{a}$ & $23.80 \pm 1.08 \mathrm{~b}$ & $3.57 \pm 0.46 \mathrm{a}$ & $14.22 \pm 1.34 \mathrm{a}$ \\
$\mathrm{T} 2$ & $1.47 \pm 0.07 \mathrm{a}$ & $24.10 \pm 1.31 \mathrm{~b}$ & $3.22 \pm 0.15 \mathrm{a}$ & $13.38 \pm 1.45 \mathrm{a}$ \\
$\mathrm{T} 3$ & $1.45 \pm 0.18 \mathrm{a}$ & $21.90 \pm 0.25 \mathrm{~b}$ & $3.17 \pm 0.12 \mathrm{a}$ & $12.10 \pm 0.58 \mathrm{a}$ \\
$\mathrm{T} 4$ & $1.85 \pm 0.27 \mathrm{a}$ & $27.55 \pm 1.25 \mathrm{a}$ & $4.01 \pm 0.38 \mathrm{a}$ & $16.84 \pm 2.06 \mathrm{a}$ \\
\hline
\end{tabular}

Mean values ( $\mathrm{n}=5 \pm$ standard error); different letters in the same column differ significantly by the Duncan test $(p \leq 0.05)$. C - Control; T1 - Treatment 1; T2 - Treatment 2; T3 - Treatment 3; T4 - Treatment T4.

The values presented in table 2, referring to the morphological development of the plants until the end of the vegetative stage (V6), are lower when compared to other crop plantations evaluated at the same age. This is a direct result of the low rainfall in the Juranda region for the years 2018/2019, in which the region suffered from periods of severe drought as can be seen in figure 1. 


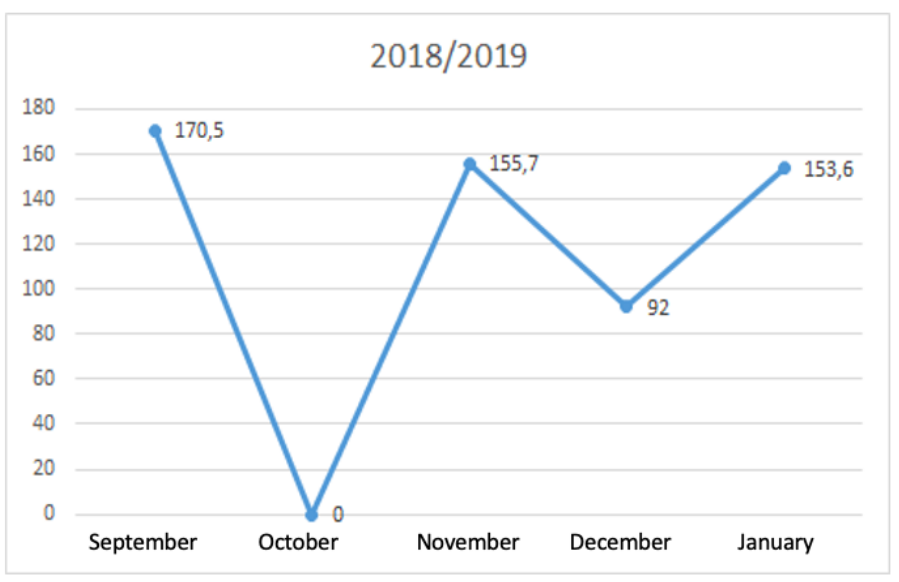

Figure 1. Rainfall values ( $\mathrm{mm}$ ) of the Primavera weather station, in the city of Juranda Paraná State, Brazil, between the months of September and January of the 2018/2019 harvest. Source: AGUASPARANÁ, 2020.

Regarding the parameters SD, RDM and SDM (Table 2), there was no significant difference among the treatments. Bulegon (2016) obtained the same responses with different treatments.

The Juranda region where the study was conducted, has a high incidence of winds. It is known that large concentrations of winds associated with plants with low stem diameter indices result in the plants lodging, generating losses in the crop development. The T1 and T4 treatments, which presented total average values higher than the other treatments, are closer to the desired characteristics that provide adequate resistance and sustainability to the plant.

The treatments showed absolute mean values higher than the control, even though they did not differ statistically, for the RDM and SDM. The explanation may be due to the fact that $A$. brasilense produced a greater amount of secondary roots. This type of roots, despite having a high volume, when converted into weight, does not reflect high responses. This result was observed by Monteiro (2013), in which was inoculated plant growth promoting bacteria to Eucalytus benthamii seedlings.

For the parameter SDM, that the present study showed the absolute mean values of the treatments were higher, due to a possible BNF. This statement is based on the statement, as already explained when presenting the results on the number and matter of nodules. However, these responses were not increased due to the water deficit that the experiment suffered mainly in October 2018 (Figure 1).

With the rainfall data in Figure 1, it is possible to state that in the experiment in stage V6 there was water restriction for the development of the plant, so the experiment presented morphological response below expectations. The cultivation of soybeans requires 400 to 900 $\mathrm{mm}$ of rain during the entire life cycle. The values shown in Figure 1, when considering the days from the date of September 26 to October 14, the period to reach the end of stage V6, there was a rainfall of only $41 \mathrm{~mm}$ (data not shown individually), which caused in subsequent problems in the flowering (R1-R3) and pod formation (R4) stages, which consequently impairs grain filling and grain maturation (R5-R8), causing a reduction in final productivity. 


\subsection{Productive Parameters}

The rain fall (Figure 1) had a direct influence on the productive response, as shown in table 3, in which all treatments for all parameters did not show considerable significant differences compared to the control.

Table 3. number of pods (NP), number of grains (NG), grains per pod (GP) and (matter of a thousand seeds MTS)

\begin{tabular}{ccccc}
\hline Treatments & NP & NG & GP & MTS \\
\hline C & $28,70 \pm 2,84 \mathrm{ab}$ & $54,27 \pm 4,53 \mathrm{ab}$ & $1,92 \pm 0,15 \mathrm{a}$ & $24,69 \pm 1,91 \mathrm{a}$ \\
& & & & \\
$\mathrm{T} 1$ & $29,25 \pm 0,92 \mathrm{ab}$ & $52,05 \pm 2,85 \mathrm{ab}$ & $1,77 \pm 0,09 \mathrm{a}$ & $23,77 \pm 2,28 \mathrm{a}$ \\
& & & & \\
$\mathrm{T} 2$ & $24,10 \pm 3,31 \mathrm{~b}$ & $43,37 \pm 3,84 \mathrm{~b}$ & $1,84 \pm 1,01 \mathrm{a}$ & $20,21 \pm 1,25 \mathrm{a}$ \\
& & & & \\
T3 & $27,05 \pm 1,37 \mathrm{ab}$ & $47,70 \pm 3,14 \mathrm{ab}$ & $1,82 \pm 0,07 \mathrm{a}$ & $21,58 \pm 1,89 \mathrm{a}$ \\
& & & & \\
T4 & $33,20 \pm 2,43 \mathrm{a}$ & $58,80 \pm 4,03 \mathrm{a}$ & $1,78 \pm 0,09 \mathrm{a}$ & $26,19 \pm 2,35 \mathrm{a}$
\end{tabular}

Mean values ( $\mathrm{n}=5 \pm$ standard error); different letters in the same column differ significantly by the Duncan test $(p \leq 0.05) . \mathrm{C}$ - Control; T1 - Treatment 1; T2 - Treatment 2; T3 - Treatment 3; T4 - Treatment 4.

The results in Table 3 indicate that for the variables NP and NG, treatment T4 obtained the higher responses, followed by control, T1 and T3. The T2 treatment obtained the lowest response for the variables NP, NG and MTS. Although the result of the T4 treatment, for MTS was superior to all other treatments, however this result was not statistically significant. It shows a trend, along with all the other variables analyzed, that there were significant gains when using the dosage used in this treatment. The data of all the analyzed parameters allow us to reaffirm that the low rainfall incidence affected the flowering, grain formation and grain filling in the present study. However, this harmful factor does not diminish the results obtained in relation to the number and matter of nodules, which are the most important variables when determining treatments with efficient BNF.

From these response, can consider that the use of co-inoculation of B. japonicum and $A$. brasilense, by spray application, due to its low cost and promising response, is a technology to be considered to assist soybeans farmers, in the search for sustainability, aiming to increase the efficiency of the use of fertilizers, such as N, with low production cost (Hungria 2015). In the way, this technology contributes to meeting the modern demands of agriculture through economic, social and environmental sustainability (Chaparro et al., 2012). 


\section{Conclusions}

It was concluded that co-inoculation by spraying in soybean crop, in the V4 stage was efficient in increasing the number and matter of nodules, plant height, number of pods and grains, more specifically with co-inoculaton of $B$. japonicum and $A$. brasilense in the dosages of $12 \times 10^{8} \mathrm{~mL}^{-1}$ of $A$. brasilense and $12 \times 10^{9} \mathrm{~mL}^{-1}$ of $B$. japonicum.

\section{References}

Abido, W. A. E., \& Omar, M. M. (2020). Bradyrhizobium and humic substances fertigation improved fertility and productivity of drip-irrigated sandy soil: Field observations on peanut (Arachis hypogaea L.). Middle East J, 9(1), 1-17. https://doi.org/10.36632/mejar/2020.9.1.1

AGUASPARANÁ - Instituto de Águas do Paraná. 2020. Available in: http://www.aguasparana.pr.gov.br/modules/conteudo/conteudo.php?conteudo=264

Bhering, S. B., Santos, H. D., Manzatto, C. V., Bognola, I., Carvalho, A. P., Potter, O., ... Carvalho Junior, W. (2007). Mapa de Solos do Estado do Paraná. Embrapa Solos-Documentos (INFOTECA-E).

Boonkerd, N., Arunsri, C., Rungrattanakasin, W., \& Vasuvat, Y. (1985). Effects of post-emergence inoculation on field grown soybeans. MIRCEN Journal of Applied Microbiology and biotechnology, 1(2), 155-161. https://doi.org/10.1007/BF01742580

Bulegon, L. G., Rampim, L., Klein, J., Kestring, D., Guimarães, V. F., Battistus, A. G., \& Inagaki, A. M. (2016). Componentes de produção e produtividade da cultura da soja submetida à inoculação de Bradyrhizobium e Azospirillum. Terra Latinoamericana, 34(2), 169-176.

Ceribeli, A. R. A. (2019). Re-inoculação de bactérias fixadoras de nitrogênio na cultura da soja e viabilidade econômica. (PhD. Thesis).

Chaparro, J. M., Sheflin, A. M., Manter, D. K., \& Vivanco, J. M. (2012). Manipulating the soil microbiome to increase soil health and plant fertility. Biology and Fertility of Soils, 48(5), 489-499. https://doi.org/10.1007/s00374-012-0691-4

Chibeba, A. M., Guimarães, M. D. F., Brito, O. R., Nogueira, M. A., Araujo, R. S., \& Hungria, M. (2015). Co-inoculation of soybean with Bradyrhizobium and Azospirillum promotes early nodulation. Embrapa Soja-Artigo em periódico indexado (ALICE).

Coniglio, A., Mora, V., Puente, M., \& Cassán, F. (2019). Azospirillum as Biofertilizer for Sustainable Agriculture: Azospirillum brasilense AZ39 as a Model of PGPR and Field Traceability. In: Microbial Probiotics for Agricultural Systems (pp. 45-70). Springer, Cham. https://doi.org/10.1007/978-3-030-17597-9_4

Crozier, A., Arruda, P., Jasmim, J. M., Monteiro, A. M., \& Sandberg, G. (1988). Analysis of indole-3-acetic acid and related indoles in culture medium from Azospirillum lipoferum and Azospirillum brasilense. Appl. Environ. Microbiol., 54(11), 2833-2837. https://doi.org/10.1128/AEM.54.11.2833-2837.1988 
de Quadros, A. S., Bandeira, L., Kasper, N., Giancotti, P. R. F., \& de Conti, L. (2020). Inoculação e coinoculação com Bradyrhizobium e Azospirillum na cultura da soja/Bradyrhizobium and Azospirillum inoculation and coinoculation in soybean culture. Brazilian Journal of Animal and Environmental Research, 3(1), 200-206.

Didonet, A. D., Lima, O. D. S., Candaten, A. A., \& Rodrigues, O. (2000). Realocação de nitrogênio e de biomassa para os grãos, em trigo submetido a inoculação de Azospirillum. Pesquisa Agropecuária Brasileira, 35(2), 401-411. https://doi.org/10.1590/S0100-204X2000000200019

Erdiansyah, I., Sari, V. K., Pratama, A. W., \& Wiharto, K. S. (2020). Utilization of Rhizobium spp as substitution agent of nitrogen chemical fertilizer on soybean cultivation. In IOP Conference Series: Earth and Environmental Science (Vol. 411, No. 1, p. 012065). IOP Publishing. https://doi.org/10.1088/1755-1315/411/1/012065

FAO - Food and Agricultural Organization. (2006). A graphical presentation of the world's agricultural trade flows, WATF. Food and Agricultural Organization of the United Nations, Economic and Social Department, The Statistics division. Available in: http://www.fao.org/es/ess/watf.asp

Galindo, F. S., Teixeira Filho, M., Buzetti, S., Ludkiewicz, M. G., Rosa, P. A., \& Tritapepe, C. A. (2018). Technical and economic viability of co-inoculation with Azospirillum brasilense in soybean cultivars in the Cerrado. Revista Brasileira de Engenharia Agrícola e Ambiental, 22(1), 51-56. https://doi.org/10.1590/1807-1929/agriambi.v22n1p51-56

Garé, L. M. (2020). Reinoculação de Rhizobium tropici no desenvolvimento e produtividade do feijoeiro em sistema plantio direto em fase inicial e consolidado. Universidade Estadual Paulista (UNESP), Brazil. 56 pp. (Ph.D. Thesis).

Groppa, M. D., Zawoznik, M. S., \& Tomaro, M. L. (1998). Effect of co-inoculation with Bradyrhizobium japonicum and Azospirillum brasilense on soybean plants. European Journal of Soil Biology, 34(2), 75-80. https://doi.org/10.1016/S1164-5563(99)90004-3

Hungria, M. (2006). Contribution of biological nitrogen fixation to the $\mathrm{N}$ nutrition of grain crops in the tropics: the success of soybean (Glycine max L. Merr.) in South America. Nitrogen nutrition in plant productivity, 43-93.

Hungria, M. (2015). The Importance of nitrogen fixation to soybean cropping in South American. p. 25-39 (No. Colección General/589.90133 N731n). In: Nitrogen fixation in agriculture, forestry, ecology, and the environment. Dordrecht, NL: Springer. https://doi.org/10.1007/1-4020-3544-6_3

Hungria, M., Franchini, J. C., Campo, R. J., \& Graham, P. H. (2005). The importance of nitrogen fixation to soybean cropping in South America. In Nitrogen fixation in agriculture, forestry, ecology, and the environment (pp. 25-42). Springer, Dordrecht.

Hungria, M., Nogueira, M. A., \& Araujo, R. S. (2013). Co-inoculation of soybeans and common beans with rhizobia and azospirilla: strategies to improve sustainability. Biology and 
Fertility of Soils, 49(7), 791-801. https://doi.org/10.1007/s00374-012-0771-5

Khomina, V., Trach, I., Semenyshyna, I., Koberniuk, O., Mudryk, K., Jewiarz, M., ... Styks, J. (2020). Potential of soybean straw in Ukraine and solid biofuel production. In Renewable Energy Sources: Engineering, Technology, Innovation (pp. 163-170). Springer, Cham. https://doi.org/10.1007/978-3-030-13888-2_15

Masciarelli, O., Urbani, L., Reinoso, H., \& Luna, V. (2013). Mecanismo alternativo para avaliação da produção de ácido indol-3-acético (IAA) por cepas de Azospirillum brasilense e seus efeitos na germinação e crescimento de mudas de milho. Journal of Microbiology, 51(5), 590-597. https://doi.org/10.1007/s12275-013-3136-3

Monteiro, P. H. R. (2013). Efeito de Bacsol® sobre o crescimento e teor de macronutrientes em mudas de Eucalyptus benthamii Maiden et Cambage. (Msc Thesys).

Pii, Y., Aldrighetti, A., Valentinuzzi, F., Mimmo, T., \& Cesco, S. (2019). A inoculação com Azospirillum brasilense neutraliza a indução da absorção de nitrato em plantas de milho. Jornal de botânica experimental, 70(4), 1313-1324. https://doi.org/10.1093/jxb/ery433

Prando, A. M., de Oliveira, A. B., Possamai, E., Reis, E., Nogueira, M., Hungria, M., ... Conte, O. (2019). Coinoculação da soja com Bradyrhizobium e Azospirillum na safra 2018/2019 no Paraná. Embrapa Soja-Circular Técnica (INFOTECA-E).

Reis Junior, F. B. D., Machado, C. T. D. T., Machado, A. T., \& Sodek, L. (2008). Inoculação de Azospirillum amazonense em dois genótipos de milho sob diferentes regimes de nitrogênio. Revista Brasileira de Ciência do solo, 32(3), 1139-1146. https://doi.org/10.1590/S0100-06832008000300022

Souza, R. A. D., Hungria, M., Franchini, J. C., Maciel, C. D., Campo, R. J., \& Zaia, D. A. M. (2008). Conjunto mínimo de parâmetros para avaliação da microbiota do solo e da fixação biológica do nitrogênio pela soja. Pesquisa Agropecuária Brasileira, 43(1), 83-91. https://doi.org/10.1590/S0100-204X2008000100011

Zilli, J. E., Marson, L. C., Campo, R. J., Gianluppi, V., \& Hungria, M. (2006). Avaliação da fixação biológica de nitrogênio na soja em áreas de primeiro cultivo no cerrado de Roraima. Embrapa Soja-Comunicado Técnico (INFOTECA-E).

Zotarelli L. (2000). Balanço de nitrogênio na rotação de culturas em sistemas de plantio direto e convencional na região de Londrina, PR. Universidade Federal Rural do Rio de Janeiro, Seropédica, Brazil. 164 pp. (Ph.D. Thesis).

\section{Copyright Disclaimer}

Copyright for this article is retained by the author(s), with first publication rights granted to the journal.

This is an open-access article distributed under the terms and conditions of the Creative Commons Attribution license (http://creativecommons.org/licenses/by/4.0/). 